\title{
Database Temperate Deciduous and Coniferous Forests of the Solling Hills
}

\author{
Wolfgang Schmidt, Michaela Dölle \& Andreas Parth
}

\begin{abstract}
The Database Temperate Deciduous and Coniferous Forests of the Solling Hills (GIVD ID EU-DE-017) offers fores vegetation relevés obtained from different research projects during four decades in the Solling Hills (Lower Saxony, Germany). It contains relevés mainly of pure beech stands (Fagus sylvatica, Luzulo-Fagetum) representing the potential natural vegetation on acidic soils of the Solling Hills. Many parts of the Solling Hills have been converted into spruce monoculture stands (Picea abies, which is not native to the region) during the last few centuries. Meanwhile a conversion of pure spruce stands into mixed stands dominated by beech is one of the main goals of silviculture in Germany. The relevés from pure beech and spruce stands as well as mixed beechspruce stands offer good opportunities e.g. to compare composition and diversity of ground layer vegetation in relation to tree species composition or to evaluate the influence of different forest management activities to species diversity. Furthermore repeated relevés on permanent plots enable an evaluation of the data regarding the impact of eutrophication (including liming) and climate change on forest ecosystems.
\end{abstract}

Keywords: Fagus sylvatica; Germany; Picea abies.

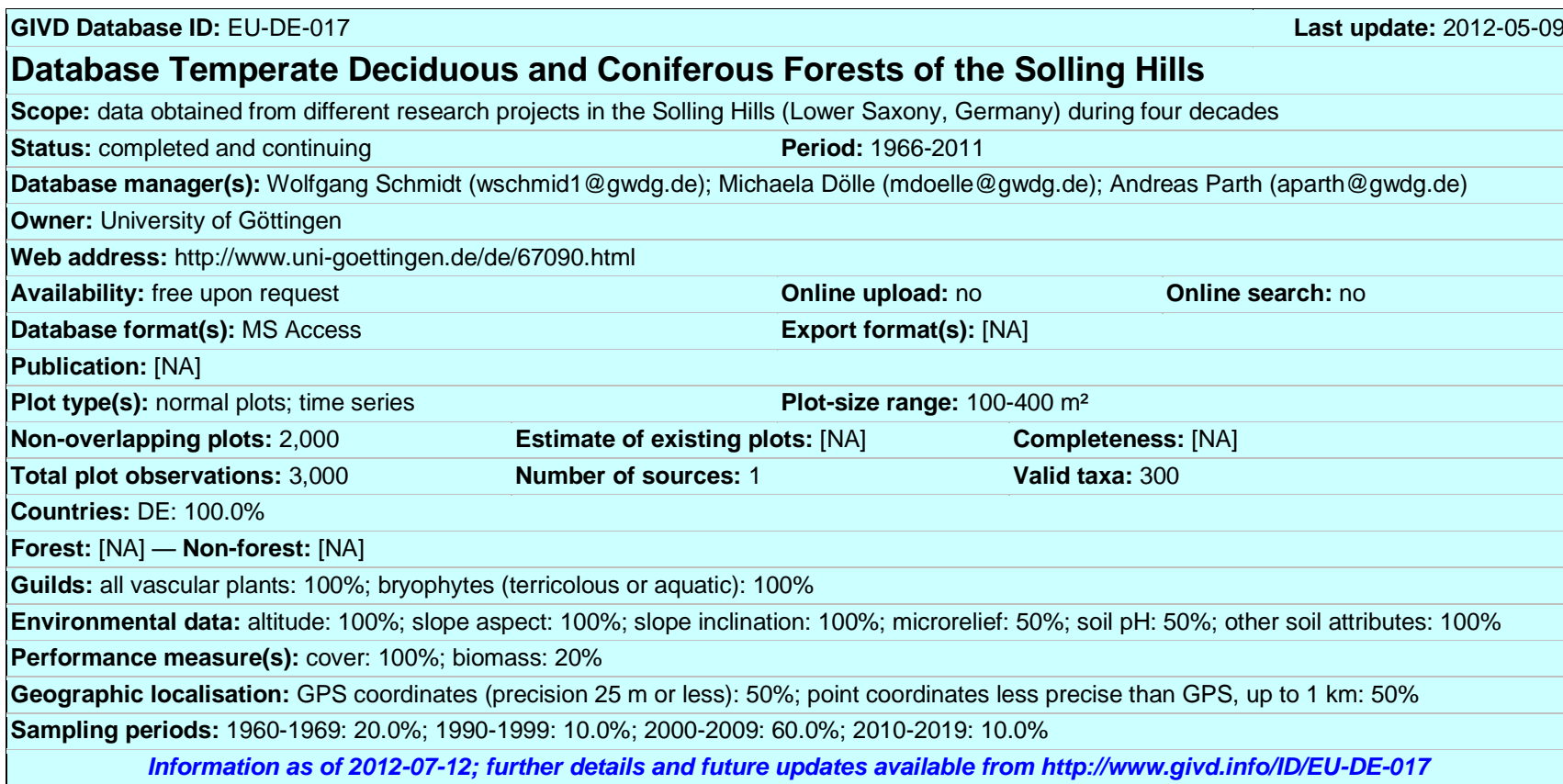

Wolfgang Schmidt (wschmid1@gwdg.de), Michaela Dölle* (mdoelle@gwdg.de), Andreas Parth (aparth@gwdg.de) Silviculture and Forest Ecology of the Temperate Zones, University of Göttingen, Büsgenweg 1, 37077 Göttingen, GERMANY

*Corresponding author 